\title{
Descriptive ecology of bat flies (Diptera: Hippoboscoidea) associated with vampire bats (Chiroptera: Phyllostomidae) in the cerrado of Central Brazil
}

\author{
Ludmilla Moura de Souza Aguiar ${ }^{1 /+}$, Yasmine Antonini² \\ ${ }^{1}$ Programa de Pós-Graduação em Ecologia, Departamento de Zoologia, Instituto de Ciências Biológicas, Universidade de Brasília, \\ Brasília, DF, Brasil Programa de Pós-Graduação em Ecologia de Biomas Tropicais, Departamento de Biodiversidade, \\ Evolução e Meio Ambiente, Instituto de Ciências Exatas e Biológicas, Universidade Federal de Ouro Preto, Ouro Preto, MG, Brasil
}

\begin{abstract}
We studied the ectoparasitic bat flies of three phyllostomid vampire bat species. Bats were collected monthly from April 2004-March 2005 in caves within the Cafuringa Environmental Protection Area in the Federal District of Brazil. A total of 1,259 specimens from six species in the Streblidae family were collected from 332 bats. High host affinity from the sampled bat fly species and high prevalence of bat flies confirms the primary fly-host associations (Strebla wiedemanni, Trichobius parasiticus and Trichobius furmani with Desmodus, Trichobius diaemi and Strebla diaemi with Diaemus and T. furmani with Diphylla). Male flies outnumbered females in several associations. Some of the observed associations (e.g., Strebla mirabilis with Desmodus and S. mirabilis, Trichobius uniformis and $\mathrm{S}$. wiedemanni with Diphylla) were inconclusive and the causes of the associations were unclear. There are several explanations for these associations, including (i) accidental contamination during sampling, (ii) simultaneous capture of several host species in the same net or (iii) genuine, but rare, ecological associations. Although various species of vampire bats share roosts, have similar feeding habits and are close phylogenetic relatives, they generally do not share ectoparasitic streblid bat flies. T. diaemi and $\mathrm{S}$. diaemi associations with Diaemus youngi have not been previously reported in this region.
\end{abstract}

Key words: cerrado - ectoparasites - Strebla diaemi - Trichobius diaemi - vampire bats

True ectoparasites spend most of their adult lives, or all developmental phases, on the bodies of their hosts or in their hosts' shelters (Marshall 1982). Streblidae (Diptera: Hippoboscoidea) are obligate ectoparasites of bats (Dick $\&$ Patterson 2008) and, consequently, are found primarily in tropical areas with relatively few species in the subtropical and warm temperate zones (Wenzel et al. 1966).

Knowledge of bat ectoparasites has provided important information on the host's biology, systematics and phylogeny (Fritz 1983) and is essential for better understanding the ecology of bats and bat behaviour in shelters. This knowledge has also explained aspects of larviposition and infestation by ectoparasites and the epidemiology of pathogen transmission in bats (Komeno \& Linhares 1999).

The host's roosting habits are important factors in the bat-ectoparasite system (ter Hofstede et al. 2004, Patterson et al. 2007, Seneviratne et al. 2009). The variability in bat roosting preferences and ectoparasite fauna provides significant insights relating to parasite ecology and specificity (ter Hofstede et al. 2004). Host specificity is typical for parasite-host associations and is often even higher in obligate or permanent parasite associa-

Financial support: PROBIO/FNMA-MMA, CNPq

+ Corresponding author: ludmillaaguiar@unb.br

Received 4 August 2010

Accepted 9 December 2010 tions (Dick et al. 2009). Ectoparasites can be classified as heteroxenous when they can infest many species in many genera, monoxenous when they are found on only one host species, stenoxenous when they are found on host species of the same genus and oligoxenous when they are found regularly on hosts of different genera (ter Hofstede et al. 2004).

The Brazilian savannah, also known as the cerrado, covers approximately two million $\mathrm{km}^{2}$ of Central Brazil and is considered one of the richest and most threatened biodiversity reservoirs in the world (Mittermeier et al. 2005). This region is responsible for most Brazilian soy and corn production and ranching in this region produces almost 40 million heads of cattle per year (Aguiar et al. 2008). Bats account for nearly $50 \%$ of the total mammalian fauna of the cerrado biome (Aguiar \& Machado 2010). This generates a great deal of concern due to their association with rabies, though most rabies cases are caused by just one vampire species, Desmodus rotundus (Gonçalves et al. 2002). Of the vampire bat species, $D$. rotundus is the most common and widespread species in Central and South America. Their primary food source is mammalian blood, but they also feed on avian blood. The two other vampire bat species, Diaemus youngi and Diphylla ecaudata, are rare and feed mainly on avian blood (Aguiar et al. 2006).

There are few studies on bat ectoparasites and their relationship with their hosts in Brazil (Gettinger \& Gribel 1989, Komeno \& Linhares 1999). At least 24 species of Streblidae have been recorded in bats in the cerrado region of Brasília (Coimbra Jr et al. 1984, Graciolli \& Coelho 2001, Graciolli \& Aguiar 2002, Aguiar et al. 
2006, Graciolli et al. 2008). The purpose of this study was to investigate the degree of host specificity of the bat flies on vampire bat species in the cerrado of Central Brazil. Previous studies of ectoparasite specificity have led us to propose the following four hypotheses: (i) different species of bats that share the same roost, belong to the same lineage and have the same habits should also share ectoparasites, (ii) more abundant bat species are parasitized by a greater number of bat fly species, (iii) there are no differences in prevalence, infestation intensity, richness and specificity of Streblidae species on bat hosts and (iv) adult parasites display a 1:1 sex ratio that is independent of the host bat's sex.

\section{MATERIALS AND METHODS}

Study area - We captured bats monthly from April 2004-March 2005 in three caves in interfluvial mesophytic forests within the Cafuringa Environmental Protection Area (EPA). EPA is located northwest of Brasília, between $15^{\circ} 30^{\prime}-15^{\circ} 40^{\prime} \mathrm{S}$ and $47^{\circ} 50^{\prime}-48^{\circ} 12^{\prime} \mathrm{W}$ and is a 46,000 ha area characterized by karst geomorphology with steep and dry relief. Dry winters and rainy summers are very characteristic of the cerrado biome, which exhibits an Aw Köppen (tropical rainy) climate (Peel et al. 2007).

Collecting and identifying ectoparasites - Streblidae flies were collected from bats captured with mist nets placed at the mouths of the following three caves: Gruta

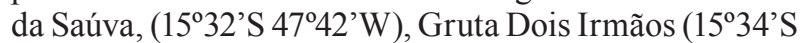
$\left.48^{\circ} 07^{\prime} \mathrm{W}\right)$ and Gruta Fenda II (15 $30^{\circ}$ 'S $\left.4810^{\prime} \mathrm{W}\right)$ (Fig. 1). One or two nylon mist-nets $(6 \times 3 \mathrm{~m})$ were used from 18:00 pm-06:00 am and the netted bats were marked, weighed, measured and released after their ectoparasites were removed. Each bat removed from the mist nets was kept in a separate cloth bag until processing to prevent ectoparasites from escaping and to avoid sample contamination. All ectoparasites observed on the bats were removed with forceps and preserved in $70 \%$ ethanol. The species of the bat flies were determined by using keys for Neotropical bat flies (Wenzel et al. 1966, Wenzel 1976, Guerrero 1993, 1994a, b, 1995a, b, 1996, 1998, Graciolli \& Carvalho 2001a, b, Miller \& Tschapka 2005). Ectoparasite species vouchers have been deposited in the Mammal Collection at the University of Brasília.

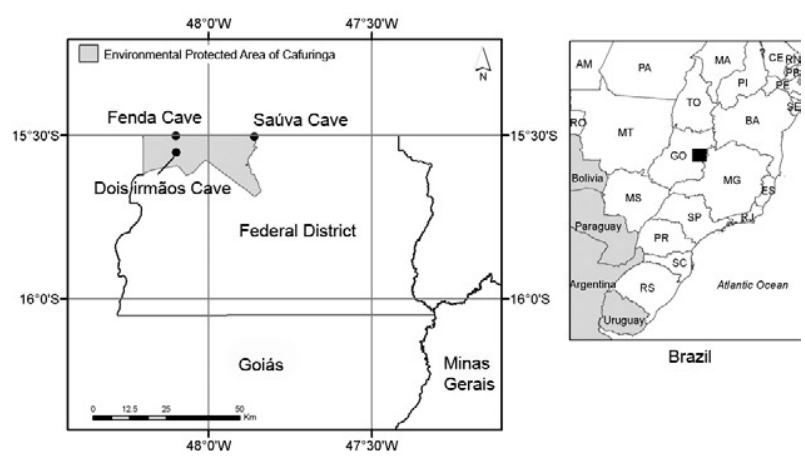

Fig. 1: map of Cafuringa Environmental Protection Area caves, in the cerrado of Federal District, Brazil.
Data analysis - We calculated the prevalence, intensity and mean intensity of infestation by parasites with the Quantitative Parasitology v3.0 software (Rózsa et al. 2000). Terminology relating to measurements of parasite variables as well as parasitism rate and relationships were as described in Bush et al. (1997). Prevalence refers to the number of infested bats per number of examined bats and is expressed as a percentage. Mean abundance refers to the number of ectoparasites per number of examined bats. Mean intensity refers to the number of ectoparasites per number of infested bats. Host specificity is the tendency of a parasite to occur on one or a few host species and is a product of the coexistence of both parasite and host species (Poulin 2007). Host specificity was calculated by using the specificity index (SI) (Marshall 1982). Associations between parasite species on the same host were tested using a Spearman correlation coefficient. The $X^{2}$ test was used to verify differences in the ectoparasite sex ratio. The same test was performed to verify differences in prevalence between host species and sex ratio in the host-parasite relationship. A t-test was used to check for differences in the abundances of ectoparasites between male and female bat hosts. Because the data for ectoparasites had a nonnormal distribution, we used a non-parametric analysis of variance (Kruskal-Wallis test) to verify the preference of specific ectoparasites for a given species of bat host. Bat hosts were the categorical variable and the number of ectoparasites of each species the continuum.

\section{RESULTS}

A total of 619 phyllostomid vampire bats belonging to three species and three genera were captured, of which 332 were infested with parasites. D. youngi were caught least often, but had the highest ratio of infestation followed by $D$. rotundus and D. ecaudata. D. rotundus $(56.49 \%)$ was the most abundant bat species captured, followed by D. ecaudata (41.08\%) and D. youngi, which was only captured eight times (2.43\%) (Table I). We collected a total of 1,259 flies of the Streblidae family, belonging to two genera and seven species. The three most abundant fly species were Strebla wiedemanni (43\%), Trichobius furmani (34\%) and Trichobius parasiticus (18\%). Trichobius diaemi, Strebla diaemi, Strebla mirabilis and Trichobius uniformis were far less abundant.

The bat fly prevalence, mean abundance and mean intensity are listed in Table I. We found specimens of $S$. diaemi and $T$. diaemi, which have not been previously reported in the cerrado of Brasília. These occurred only on D. youngi and, so, were considered to be monoxenous. Although T. uniformis occurred only on D. ecaudata, there were only five specimens and they were all collected from the same host. Four out of six bat fly species were collected from more than one host species and are thus considered oligoxenous. These were S. mirabilis, S. wiedemanni, T. furmani and T. parasiticus, and they were found on both D. rotundus and D. ecaudata.

Most bats infested with bat flies $(n=182)$ had only one bat fly species. However, the presence of more than one bat fly species on the same host was also observed (Fig. 2). D. rotundus bats were infested with four bat 
TABLE I

Prevalence (\%), mean abundances and mean intensities of host species and their ectoparasites collected at the Cafuringa Environmental Protection Area caves, Federal District, Brazil, from April 2004-March 2005

\begin{tabular}{|c|c|c|c|c|c|c|c|}
\hline \multicolumn{2}{|l|}{ Host } & \multicolumn{6}{|l|}{ Bat fly } \\
\hline Species & $\mathrm{n}$ & Species & $\mathrm{n}$ & Infested & $\begin{array}{c}\text { Mean } \\
\text { abundance }\end{array}$ & $\begin{array}{c}\text { Mean } \\
\text { intensity }\end{array}$ & $\begin{array}{c}\text { Prevalence } \\
(\%)\end{array}$ \\
\hline \multirow[t]{4}{*}{ Desmodus rotundus } & 346 & Strebla mirabilis & 1 & 1 & 0.01 & 1.00 & 0.28 \\
\hline & & Strebla wiedemanni & 540 & 151 & 1.56 & 3.57 & 43.6 \\
\hline & & Trichobius furmani & 57 & 37 & 0.16 & 1.54 & 10.7 \\
\hline & & Trichobius parasiticus & 214 & 102 & 0.62 & 2.09 & 29.5 \\
\hline \multirow[t]{2}{*}{ Diaemus youngi } & 8 & Trichobius diaemi ${ }^{a}$ & 84 & 8 & 10.5 & 10.5 & 100 \\
\hline & & Strebla diaemi ${ }^{a}$ & 51 & 8 & 6.37 & 6.37 & 100 \\
\hline \multirow[t]{5}{*}{ Diphylla ecaudata } & 265 & Trichobius furmani & 372 & 114 & 1.41 & 3.26 & 43 \\
\hline & & Trichobius parasiticus & 9 & 4 & 0.03 & 2.25 & 1.51 \\
\hline & & Strebla mirabilis & 6 & 5 & 0.02 & 1.20 & 1.88 \\
\hline & & Trichobius uniformis & 5 & 1 & 0.01 & 5.00 & 0.37 \\
\hline & & Strebla wiedemanni & 4 & 3 & 0.01 & 1.33 & 1.13 \\
\hline Total & 619 & & 1,259 & 434 & - & 2.16 & - \\
\hline
\end{tabular}

a: first record for the Brazilian cerrado region and Federal District.

fly species and both $S$. wiedemanni and $T$. parasiticus were present in high abundance (sample size $>100$ ). Individuals of $D$. rotundus with more than two bat fly species were also found, but they rarely had more than one or two specimens of a third bat fly species. However, there was one $D$. rotundus bat with 25 specimens of bat flies. The highest numbers of infracommunities (all the ectoparasite species in a single individual host) were found on this bat species. Two associations were with three species of flies and two associations were always formed by $T$. furmani and $S$. wiedemanni. Three associations had two species, where two of these associations included $S$. wiedemanni and one included the Trichobius species (Fig. 2). D. ecaudata were infested with five bat fly species, only one of which one was abundant $(T$. furmani, with sample size $>100$ ). There were only five or fewer specimens of other bat flies on D. ecaudata. The D. ecaudata individuals with more bat flies had 14 specimens. Three infracommunities were found on individuals of this bat species. One infracommunity included three species of flies and the other two included two species of flies, one of which was T. furmani (Fig. 2). D. youngi had one established infracommunity with eight associations composed of the $S$. diaemi and $T$. diaemi species of flies (Fig. 2). None of these bat flies were "dominant" species and the specimens were in relatively large numbers. The individual bat with the greatest number of bat flies had 22 specimens.

The SI presented a maximum value $(100 \%)$ in three fly species associations: $S$. diaemi and $T$. diaemi on $D$. youngii and T. uniformis on D. ecaudata. A lower SI value was found for $S$. wiedmanni and $T$. parasiticus on $D$. ecaudata (Table II).
We found that the ectoparasites $T$. uniformis and $S$. mirabilis do not show preferences for bat species. $T$. furmani and $T$. parasiticus preferentially parasitized $D$. ecaudata over D. rotundus $\left[\mathrm{F}_{(1,322)}=148.98, \mathrm{p}<0.05\right]$. $S$. mirabilis preferentially appeared on $D$. rotundus $\left[\mathrm{F}_{(1,322)}\right.$ $=57.630, \mathrm{p}<0.05$ and $\left.\mathrm{F}_{(2,328)}=58.565, \mathrm{p}=0.0000\right]$. T. diaemi and $S$. diaemi prefer D. youngi $\left[\mathrm{F}_{(2,328)}=206.71, \mathrm{p}\right.$ $=0.0000$ and $\mathrm{F}_{(2,328)}=196.48, \mathrm{p}=0.0000$, respectively]. However, there was a significant, although weak, negative association between $T$. parasiticus and $T$. furmani when the two species co-parasitized D. rotundus $\left(r_{S}=\right.$

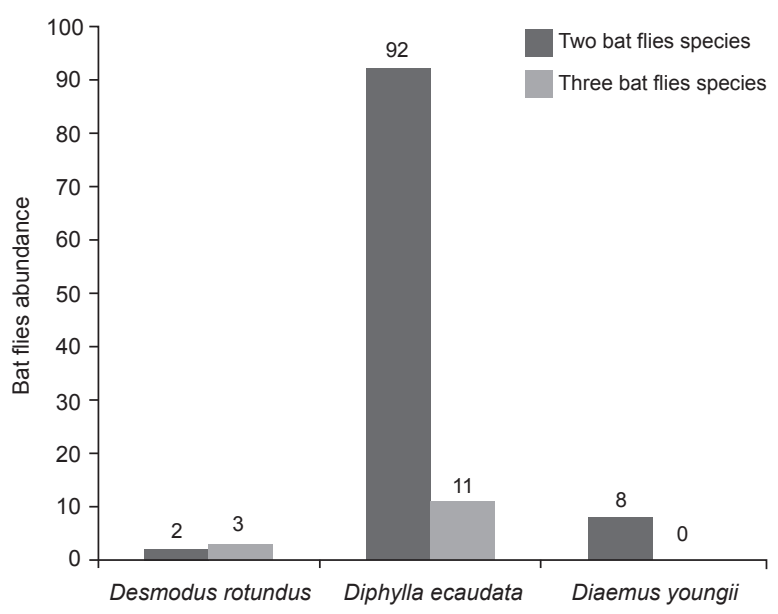

Fig. 2: total number of infested hosts captured from April 2004March 2005 at the Cafuringa Environmental Protection Area caves, the Federal District (FD), Brazil. 


\section{TABLE II}

Specificity index in percentage values and number of males, females and the value of $\mathrm{p}$ in sex ratio tests for Streblidae captured on bats from April 2004-March 2005 at the Cafuringa Environmental Protection Area caves, in the cerrado of the Federal District, Brazil

\begin{tabular}{|c|c|c|c|c|c|c|}
\hline \multirow[b]{2}{*}{ Ectoparasites } & \multicolumn{6}{|c|}{ Hosts } \\
\hline & Desmodus rotundus & Diphylla ecaudata & Diaemus youngii & Male & Female & $\mathrm{p}$ value \\
\hline Strebla diaemi & - & - & 100 & 25 & 26 & $<0.841$ \\
\hline Strebla mirabilis & 25 & 83.3 & - & 3 & 4 & - \\
\hline Strebla wiedemanni & 97.5 & 1.9 & - & 303 & 224 & $<0.005^{a}$ \\
\hline Trichobius diaemi & - & - & 100 & 43 & 8 & $<0.00^{a}$ \\
\hline Trichobius furmani & 45 & 57 & - & 221 & 204 & $<0.408$ \\
\hline Trichobius parasiticus & 95 & 3.8 & - & 126 & 93 & $<0.025^{a}$ \\
\hline Trichobius uniformis & - & 100 & - & 2 & 3 & - \\
\hline
\end{tabular}

$a$ : statistically significant.

- 0.49; $\mathrm{p}<0.05)$. The same weak negative association was found for $T$. parasiticus and $T$. furmani when they co-occurred on D. ecaudata $\left(r_{S}=-0,17\right.$; $\left.\mathrm{p}<0.05\right)$.

Three out of the seven species of flies had male-biased sex ratios ( $S$. wiedmani, $T$. parasiticus and $T$. diae$m i)$. For the other two species, the sex ratio was close to one with no significant differences (Table II). Due to the small number of collected specimens, no analysis was performed for differences in the sex ratio for $S$. mirabilis and T. uniformis. Of all parasites found in this study, $20 \%$ of the ectoparasite species were common in both $D$. rotundus and $D$. ecaudata. These two bat species do not share ectoparasites with D. youngi. We found that male and female vampire bats are parasitized in equivalent ways, regardless of sex (Table III). Male and female ectoparasites do not show preference for the host's sex, although there was a tendency for $D$. rotundus to be parasitized by male $S$. wiedemanni and $T$. parasiticus.

\section{DISCUSSION}

Caves are environments with stable temperature and humidity conditions. Streblidae deposit their pre-pupae on cave surfaces within these stable environments and, consequently, parasites have easy access to bat hosts living in this habitat (ter Hofstede et al. 2004). D. rotundus was the most abundant species in the study area and was also the species with the largest number of ectoparasites. D. young $i$ was the least abundant species and also exhibited the fewest ectoparasite species.

Although we captured a significant number of bats and Streblid individuals, the latter were restricted to only two genera (Strebla and Trichobius). Neotropical Strebla species specialize in parasitising Phyllostomidae (Guerrero 1996) and are very active insects (Wenzel et al. 1966, Guerrero 1994b, Graciolli \& Carvalho 2001b). This mobility, associated with shelter-sharing by more than one bat species, explains the occurrence of accidental or transitory parasitism such that observed for $T$. uniformis. This bat flies usually found on nectarivorous

\section{TABLE III}

Chi-square values to assess the differences in prevalence among the three host species at the Cafuringa Environmental Protection Area caves, Federal District, Brazil, from April 2004-March 2005

\begin{tabular}{lcc}
\hline Species & $\mathrm{X}^{2}$ value & $\mathrm{p}$ value \\
\hline Strebla diaemi & 316,19 & 0.0023 \\
Strebla mirabilis & 319 & 0.0037 \\
Trichobius diaemi & 93,3 & 0.0021 \\
Strebla wiedemanni & 315,19 & 0.005 \\
Trichobius furmani & 98,67 & 0.0032 \\
Trichobius uniformis & 155,2 & 0.0001 \\
Trichobius parasiticus & 330,03 & 0.0027 \\
\hline
\end{tabular}

phyllostomid bats of the genus Glossophaga Geoffroy (Guerrero 1994a). The bat fly species T. uniformis has been previously reported in Pernambuco, Minas Gerais (Guimarães 1937), Roraima (Graciolli \& Linardi 2002), as well as in the Federal District (FD) (Graciolli \& Coelho 2001), where it was found to be parasitized by the Laboulbeniomycetes fungus. We found $T$. uniformis on $D$. ecaudata, which may constitute an accidental or transitory parasitism reinforced by the presence of Glossophaga soricina in the caves sampled in Central Brazil (LMS Aguiar, unpublished observations). The same circumstances apply for $S$. mirabilis, which is not a typical parasite of $D$. rotundus or D. ecaudata, although it has been found on these species and on many others (e.g., Trachops cirrhosus) (ter Hofstede et al. 2004). S. mirabilis is found from Mexico to Paraguay and, in Brazil, its presence has been recorded in the states of Pará (PA), Paraná (PR), Rio de Janeiro and FD (Graciolli et al. 2008). In a broad study conducted in Paraguay, Dick and Gettinger 2005 had found that the specificity of Stre- 
blidae is high and that natural transfers are rare. He had observed that contaminations occurred due to parasite disturbance during the capture and handling of the bats.

The other bat flies were characteristic of their host species. S. diaemi occurs in Argentina, Brazil, Bolivia, Colombia, Panamá, Peru and Venezuela. In Brazil, it has been found in PR, São Paulo and PA. It is a typical ectoparasite of D. youngi, although it has also been found on D. ecaudata Spix, Carollia perspicillata (Linnaeus) and Sturnira lilium (E. Geoffroy) (Guerrero 1996, Graciolli \& Carvalho 2001a, b).

T. diaemi is characteristic of D. youngi and, as far as we know, there are no published records of this species in Brazil. This bat fly was described in Venezuela (Wenzel 1976). D. youngi is the typical host, but $T$. diaemi can also be found on D. rotundus (Guerrero 1995b). The T. diaemi and $S$. diaemi specimens we found are range extensions associated with sampling increase in the cerrado biome and it was expected that the distribution range of these bat flies included the FD region.

$S$. wiedemanni is a characteristic ectoparasite of $D$. rotundus and occurs in Argentina, Brazil, Bolivia, Colombia, Ecuador, El Salvador, Guatemala, Honduras, Mexico, Panamá, Peru, Suriname, Trinidad and Venezuela (Wenzel 1970, Guerrero 1996, 1997, Autino \& Claps 2000). In Brazil, it had already been recorded in the cerrado region on D. rotundus (Coimbra Jr et al. 1984, Komeno \& Linhares 1999, Desidério et al. 2000, Graciolli \& Coelho 2001) and D. ecaudata (Coimbra Jr et al. 1984).

T. furmani belongs to the parasiticus complex (Wenzel \& Tipton 1966) and has been recorded by Coimbra Jr et al. (1984) and Graciolli and Coelho (2001) on D. rotundus and D. ecaudata. Apparently, it is commonly found on these species in the cerrado biome.

T. parasiticus is also characteristic of the D. rotundus vampire bat and is found in all the geographic locations where its host occurs, except for Southern Brazil where it seems to be displaced by $T$. furmani (Graciolli \& Linardi 2002).

Interestingly, in this study, we observed a negative association between T. parasiticus and T. furmani independent of their host species $(D$. rotundus and D. ecaudata). This fact may indicate that these two congener bat flies are competitors independent of the host and further studies are needed to determine how and why the presence of one species decreases the abundance of the other. It is also possible that the two parasite species show a preference for each one of the bat hosts, but this result may be only a statistical artefact. Nonetheless, Dick and Gettinger (2005) remark that in Paraguay D. rotundus and D. youngi were not hosts to T. furman, and they cite Wenzel et al. (1966) in suggesting that T. furmani is replaced by T. parasiticus in some parts of South America. These two observations may corroborate our hypothesis of competition between these two parasitic species, but further studies must be conducted to clarify the relationship between these two bat fly species. Because D. rotundus is usually spatially separated from other bat species using the same roost, it is reasonable to assume that the presence of the two typical $D$. rotundus ectoparasites on other host bat species may occur due to transient or accidental associations, as suggested previously.
In the present study, the various parasitic species were found to be abundant on different host species. This observation is consistent with the findings of Esberrard et al. (2005), which indicate that the determination of host specificity of a parasite is a very complex issue involving anatomical, physiological, evolutionary and behavioural adaptations. Further studies should be carried out to assess spatial and temporal infestation preferences in different regions of the host body and at different times of the day (Bittencourt \& Rocha 2002) and to increase our understanding of some of the complicating factors that determine host specificity. Despite the reduced number of captures, 144 bat flies were found on D. youngi. Two examples are noteworthy. Female number 310 had $22 T$. diaemi and $13 S$. diaemi specimens, while female number 271 had 19 T. diaemi and $18 S$. diaemi specimens. In D. rotundus, both sex and relatedness influence individual allogrooming rates (Wilkinson 1986). Such cases of high infestation can contribute not only to deterioration of host health, but they can also interfere with social interactions. The study region has a strong seasonality, with rainfall from October-March and a dry season from April-September. Diaemus individuals were collected only during the rainy season and prevalence and infestation by bat flies could vary throughout the year. Marshall (1982) states that temperature influences many aspects of ectoparasite biology, especially reproduction, and that low temperature and humidity may lead to mortality of ectoparasitic insects.

The higher proportion of male flies captured in this study is in accordance with findings from other studies (Dick \& Patterson 2008) that show that male-biased sex ratios of parasites on foraging bats may reflect the relative times that males and females spend on the host, including the times females choose to larviposit. Dick and Patterson (2008) have also presented the hypothesis that male ectoparasites may have no reason to leave the host and could be permanent residents on bats, because mating often occurs on the host. Thus, it is expected that if sexes are biased, then the bias should favour finding males on the host.

Although female bats show greater prevalence and intensity of infestation by parasites than males (Dick \& Patterson 2008), we found that males and females were parasitized to the same extent in the present study. However, $D$. rotundus showed a greater tendency of being parasitized by $S$. wiedemanni males $\left(X^{2}=9.67, \mathrm{p}=0.001\right)$.

Few studies have been conducted in Brazil relative to the quantitative parasitism patterns of Streblidae on their hosts. The available data show that the mean abundance registered for the cerrado was 0.9 (Azevedo \& Linardi 2002), compared to the southern Atlantic rainforest values of 0.54 and 0.61 (Graciolli \& Rui 2001, Bertola et al. 2005). In the present study, prevalence, mean intensity of infestation and mean abundance were high for all three hematophagous bat species. Factors that may influence parasitism rates include the type of shelter used by the bat host, the associations between different species of bats in the shelters and host-parasite behaviour (Komeno $\&$ Linhares 1999). The high rates of infestation (preva- 
lence and mean intensity) of the populations of $D$. rotun$d u s, D$. youngi, and D. ecaudata probably result from the combination of several factors.

Caves are considered favourable shelters for bats and their parasites because they provide a favourable microclimate. In such habitats, although seasonally variable, bat colonies may include several hundred individuals. The bat species studied here live in colonies with variable numbers of individuals and there are indications that these species have occupied these roosts for a long period of time (LMS Aguiar, unpublished observations). Because bats are periodically displaced and usually leave their shelters only for feeding, infestation and modification in the population structure of ectoparasite species are unlikely to occur (Komeno \& Linhares 1999). Because the bats studied here lived in these caves for a long period, we expected to observe higher levels of infection than we did.

The hypothesis that ecologically similar species would share common ectoparasites even living in polyspecific roosts was supported by the two associations between $D$. rotundus and D. ecaudata, but none with D. youngi. The association with $D$. youngi was probably not found because it occurs only in a certain period of the year. This contrasts with the suggestion made by ter Hofstede et al. (2004) that ectoparasites are more likely to be alike among members of the same genus than among species of different genera using the same roost. Thus far, 26 bat fly species have been identified in the FD region. However, this figure is bound to increase as more bats are examined. We found that although the bat species studied here share roosts, feeding habits and phylogeny, they do not share ectoparasites. T. furmani and T. parasiticus are typically found on $D$. rotundus, but in this study, $T$. furmani preferentially parasitized $D$. ecaudata individuals instead of $D$. rotundus individuals.

\section{ACKNOWLEDGEMENTS}

To Dr Gustavo Graciolli, who taught Alexandre de Souza Portella to identify the ectoparasites, to Willian Rogers de Camargo, for support in field work, to Carlos Esberárd, Donald Gettinger and Carl Dick, who read an early version of the manuscript and made invaluable suggestions, and to Regina Macedo, who helped us with English.

\section{REFERENCES}

Aguiar LMS, Camargo AJA, Moreira JR 2008. Serviços ecológicos prestados pela fauna na agricultura do cerrado. In LM Parron, LMS Aguiar, E Duboc, EC Oliveira-Filho, AJA Camargo, FG Aquino (ed.), Cerrado: desafios e oportunidades para o desenvolvimento sustentável, Embrapa Cerrados, Brasília, p. 193-228.

Aguiar LMS, Camargo WR, Portella AS 2006. Occurrence of whitewinged vampire bat, Diaemus youngi (Mammalia, Chiroptera), in the cerrado of Distrito Federal, Brazil. Rev Bras Zool 23: 893-896.

Aguiar LMS, Machado RB 2010. Áreas prioritárias para a pesquisa de morcegos no domínio do cerrado. In IR Diniz, J MarinhoFilho, RB Machado, RB Cavalcanti (organizadores), Cerrado: conhecimento científico quantitativo como subsídio para ações de conservação, Thesaurus, Brasília, p. 425-440.

Autino AG, Claps GL 2000. Catalogue of the ectoparasitic insects of the bats of Argentina. Insecta Mundi 14: 193-209.
Azevedo AA, Linardi PM 2002. Streblidae (Diptera) of Phyllostomid bats from Minas Gerais, Brazil. Mem Inst Oswaldo Cruz 97: 421-422.

Bertola PB, Aires CC, Favorito SE, Graciolli G, Amaku M, Pintoda-Rocha R 2005. Bat flies (Diptera: Streblidae, Nycteribiidae) parasitic on bats (Mammalia: Chiroptera) at Parque Estadual da Cantareira, São Paulo, Brazil: parasitism rates and host-parasite associations. Mem Inst Oswaldo Cruz 100: 25-32.

Bittencourt EB, Rocha CFD 2002. Spatial use of rodents (Rodentia: Mammalia) host body surface by ectoparasites. Bras J Biol 62: 419-425.

Bush AO, Lafferty KD, Lotz JM, Shostak AW 1997. Parasitology meets ecology on its own terms: Margolis et al. revisited. J Parasitol 83: 575-583.

Coimbra Jr CEA, Guimarães LR, Mello DA 1984. Ocorrência de Streblidae (Diptera: Pupipara) em morcegos capturados em regiões de cerrado do Brasil Central. Rev Bras Entomol 28: 547-550.

Desidério MHG, Santos HD, Sá-Freire L, Serra-Freire NM 2000. Registro do encontro de Strebla (Diptera: Streblidae) em Desmodus rotundus (Mammalia: Chiroptera) capturado em Tocantins, Brasil. Rev Cienc Biol Saude 1: 98-100.

Dick C, Esbérard C, Graciolli G, Bergallo H, Gettinger D 2009. Assessing host specificity of obligate ectoparasites in the absence of dispersal barriers. Parasitol Res 105: 1345-1349.

Dick CW, Gettinger D 2005. A faunal survey of Streblidae flies (Diptera: Streblidae) associated with bats in Paraguay. J Parasitol 91: 1015-1024.

Dick CW, Patterson BD 2008. An excess of males: skewed sex ratios in bat flies (Diptera: Streblidae). Evol Ecol 22: 757-769.

Esbérard CEL, Martins-Hatano F, Bittencourt EB, Bossi DEP, Fontes A, Lareschi M, Menezes V, Bergallo HG, Gettinger D 2005. A method for testing the host specificity of ectoparasites: give them the opportunity to choose. Mem Inst Oswaldo Cruz 100: 761-764.

Fritz GN 1983. Biology and ecology of bat flies (Diptera: Streblidae) on bats in the genus Carollia. J Med Entomol 20: 1-10.

Gettinger D, Gribel R 1989. Spinturnicid mites (Gamasida: Spinturnicidae) associated with bats in Central Brazil. J Med Entomol 26: 491-493.

Gonçalves MA, Sá-Neto RJ, Brazil TK 2002. Outbreak of aggressions and transmission of rabies in human beings by vampire bats in Northeastern Brazil. Rev Soc Bras Med Trop 35: 461-464.

Graciolli G, Aguiar LS 2002. Ocorrência de moscas ectoparasitas (Diptera, Streblidae e Nycteribiidae) de morcegos (Mammalia, Chiroptera) no cerrado de Brasília, Distrito Federal, Brasil. Rev Bras Zool 19 (Suppl. 1): 177-181.

Graciolli G, Azevedo AA, Árzua M, Barros-Battesti DM, Linardi PM 2008. Artrópodos ectoparasitos de morcegos no Brasil. In S Pacheco, RV Marques, CEL Esbérard (orgs.), Morcegos no Brasil: biologia, sistemática, ecologia e conservação, 1st ed., Armazém Digital, Porto Alegre, p. 123-138.

Graciolli G, Carvalho CJB 2001a. Moscas ectoparasitas (Diptera, Hippoboscoidea, Nycteribiidae) de morcegos (Mammalia, Chiroptera) do estado do Paraná, Brasil. I. Basilia, taxonomia e chave pictórica para as espécies. Rev Bras Zool 18 (Suppl. 1): 33-49.

Graciolli G, Carvalho CJB 2001b. Moscas ectoparasitas (Diptera, Hippoboscoidea, Nycteribiidae) de morcegos (Mammalia, Chiroptera) do estado do Paraná, Brasil. II. Streblidae. Chave pictórica para gêneros e espécies. Rev Bras Zool 18: 907-960.

Graciolli G, Coelho DC 2001. Streblidae (Diptera: Hippoboscoidea) sobre morcegos filostomídeos (Chiroptera: Phyllostomidae) em cavernas do Distrito Federal, Brasil. Rev Bras Zool 18: 965-970. 
Graciolli G, Linardi PM 2002. Some Streblidae and Nycteribiidae (Diptera: Hippoboscoidea) from Maracá Island, Roraima, Brazil. Mem Inst Oswaldo Cruz 97: 139-141.

Graciolli G, Rui AM 2001. Streblidae (Diptera, Hippobocoidea) em morcegos (Chiroptera, Phyllostomidae) no nordeste do Rio Grande do Sul, Brasil. Iheringia Zool 90: 85-92.

Guerrero R 1993. Catalogo de los Streblidae (Diptera: Pupipara) parasitos de murciélagos (Mammalia: Chiroptera) del Nuevo Mundo. II. Clave para los géneros y Nycterophillinae. Acta Biol Venez 14: 61-75.

Guerrero R 1994a. Catalogo de los Streblidae (Diptera: Pupipara) parasitos de murciélagos (Mammalia: Chiroptera) del Nuevo Mundo. II. Los grupos: pallidus, caecus, major, uniformis y longipes del género Trichobius Gervais, 1844. Acta Biol Venez 15: 1-18.

Guerrero R 1994b. Catalogo de los Streblidae (Diptera: Pupipara) parasitos de murciélagos (Mammalia: Chiroptera) del Nuevo Mundo. IV. Trichobiinae com alas desarrolladas. Bol Entomol Venez 9: 161-192.

Guerrero R 1995a. Catalogo de los Streblidae (Diptera: Pupipara) parasitos de murciélagos (Mammalia: Chiroptera) del Nuevo Mundo. III. Los gupos: dugesii, dunni y phyllostomae del género Trichobius Gervais, 1844. Acta Biol Venez 15: 1-27.

Guerrero R 1995b. Catalogo de los Streblidae (Diptera: Pupipara) parasitos de murciélagos (Mammalia: Chiroptera) del Nuevo Mundo. V. Trichobiinae con alas reducidas o ausentes y miscelaneos. Bol Ent Venez 10: 135-160.

Guerrero R 1996. Catalogo de los Streblidae (Diptera: Pupipara) parasitos de murciélagos (Mammalia: Chiroptera) del Nuevo Mundo. VI. Streblinae. Acta Biol Venez 16: 1-25.

Guerrero R 1997. Catalogo de los Streblidae (Diptera: Pupipara) parasitos de murcielagos (Mammalia: Chiroptera) del nuevo mundo. VII. Lista de especies, hospedadores y paises. Acta Biol Venez 17: 9-24.

Guerrero R 1998. Notes on Neotropical batflies (Diptera: Streblidae). II. Review of the genus Xenotrichobius. Acta Parasitol 43: 142-147.

Guimarães LR 1937. Sobre as espécies sul americanas do gênero Trichobius (Diptera: Streblidae). Rev Museu Paulista 23: 653-666.

Komeno CA, Linhares AX 1999. Bat flies parasitic on some phyllostomid bats in Southeastern Brazil: parasitism rates and hostparasite relationships. Mem Inst Oswaldo Cruz 94: 151-156.
Marshall AG 1982. Ecology of insects ectoparasitic on bats. In TH Kunz, Ecology of bats, Plenum Publishing, New York, p. 369-401.

Miller J, Tschapka M 2005. Batflies of la selva (Diptera: Nycteribiidae, Streblidae). Accessed in 2005 May 3. Available from: http:// www.biologie.uni-ulm.de/bio3/Batfly/index.html.

Mittermeier RA, Robles Gil G, Hoffmann M, Pilgrim J, Brooks T, Mittermeier CG, Lamoreux J, Fonseca GAB 2005, Hotspots revisited, CEMEX, Mexico City, 392 pp.

Patterson BD, Dick CW, Dittmar K 2007. Roosting habits of bats affect their parasitism by bat flies (Diptera: Streblidae). $J$ Trop Ecol 23: 177-189.

Peel MC, Finlayson BL, McMahon TA 2007. Updated world map of the Köppen-Geiger climate classification. Hydrol Earth Syst Sci 11: $1633-1644$.

Poulin R 2007. Evolutionary ecology of parasites, 2nd ed., Chapman and Hall, London, $342 \mathrm{pp}$.

Rózsa L, Reiczigel J, Majoros G 2000. Quantifying parasites in samples of hosts. J Parasitol 86: 228-232.

Seneviratne SS, Fernando HC, Udagama-Randeniya PV 2009. Host specificity in bat ectoparasites: a natural experiment. Int J Parasitol 39: 995-1002.

ter Hofstede HM, Fenton MB, Whitaker Jr JO 2004. Host and hostsite specificity of bat flies (Diptera: Streblidae and Nycteribiidae) on Neotropical bats (Chiroptera). Can J Zool 82: 616-626.

Wenzel RL 1970. Family Streblidae. In N Papavero (ed.), A catalogue of the Diptera of the Americas South of the United States, Museu de Zoologia, São Paulo, 25 pp.

Wenzel RL 1976. The streblid bat flies of Venezuela (Diptera: Streblidae). Brigham Young Univ Sci Bull Biol Ser 20: 1-177.

Wenzel RL, Tipton VJ 1966. Some relationships between mammal hosts and their ectoparasites. In RL Wenzel, VJ Tipton (eds.), Ectoparasites of Panama, Field Museum of Natural History, Chicago, p. 677-723.

Wenzel RL, Tipton VJ, Kiewlicz A 1966. The streblid bat flies of Panama (Diptera: Calyptera: Streblidae), In RL Wenzel, VJ Tipton (eds.), Ectoparasites of Panama, Field Museum of Natural History, Chicago, p. 405-675.

Wilkinson GS 1986. Social grooming in the common vampire bat, Desmodus rotundus. Anim Behav 34: 1880-1889. 